direction of treatment: they forget, or have never realised, that the cause of that change is the highest attribute of human reason, namely, the power of discovering what is wrong and the endeavour to replace it by something better. To them it is as if treatment of disease was a haphazard sort of affair, and in which the determination of what should or what should not be done in this or that or the other disease was a matter of chance, or of what is falsely called experience. To us, however, who know the true aspect of the question, it presents itself in a totally different light. We see that our knowledge is daily increasing, is daily acquiring a more scientific basis, and therefore I would say to all, that as far as all your interests in merely living in this world are concerned you have chosen the best possible means of gaining an honourable success. If you work you cannot fail.

There is one more side of the subject of which I should like to say a few words in conclusion. You have to remember that while a unit in a large profession, that profession is but one among various communities of men, and consequently in your future you must also think both of what you owe to your profession and science, as well as to the community at large. The first duty of every one of us is, it seems to me, to join with his brethren, so that by union the profession can stand and act together. At the present moment the representation of the profession in the House of Commons is about one-half per cent. As for the House of Lords, which decides many questions of the utmost importance to sanitation and to general medicine, it is composed of many noblemen, a large share of lawyers, a few bishops and generals, and one poet, but no representative of our profession or of science. What can be more absurd or unreasonable: Even with the unity and strength which the British Medical Association affords, it is difficult to it sist arbitrary acts being placed on the -tatute Book by statesmen who know about as much of the requirements of the profession as we should of the means of circumventing Russia, or keeping France tolerably quiet for a week at a time. There is, however, another way in which we can gain strength from bodies outside our own, which we can obtain more and more, exactly in proportion as we seek to elevate our profession by cultivating the scientific side of it, and thus bringing it in touch with all other branches of science. $A$ striking proof of the value of this union with other scientific men was recently given by the decision of the President of the Board of Trade, in reference to the Bactericlogical Institute, and I should therefore like to allude to it now. As you may know, it became necessary that the great central and national Bacteriological Institute, which is now being founded, should be registered in order to guarantee that the fund raised could not be devoted to any other purpose. Sir Michael Hicks-Beach, misled by some unprincipled persons, refused to sanction the registration, and, in doing so, revealed the fact that he was utterly ignorant, not only of the charitable and beneficent labours of such institutes, but also of the laws relating to the subject, Although in this extraordinary state of mind he was so influenced that he would have decided unfavourably to the scheme, concerted action on the part of the profession, backed up and supported by the sympathetic efforts of all other branches of science, enabled us to overcome the difficulties before us, and to obtain the registration we demanded.

It is incumbent, therefore, upon all of us to unite together, and, in spite of its defects, the best way to do this is, I believe. to join the British Medical Association. No human organisa tion was or is likely to be perfect, and the Association is no exception to the rule. But that it is of the greatest service to the profession none can doubt, and future reform will make it better than it is now. Joining it will bring you into line with and in touch with your fellow practitioners. You will not feel that you are living only for yourself, but that the opportunity is before you of adding your weight to the furtherance of plans which should tend to the welfare and advancement of the profession, and of helping to resist burdens and attacks which will always be thrust upon us.

Finally, let me once more congratulate you on entering a profession in which honest work is sure to succeed, in which the actual work is always interesting and always advancing, and, in congratulating you, thank you for the attention you have accorded these few remarks.

\section{ON TAKING PAINS.}

\section{Delivered at the Distribution of Prizes at St. Thomas's Hospital.}

By Sin GEORGE M. HUMPHRY, F.R.S., Professor of Surgery University of Cambridge.

Gentlemen,-Let me first congratulate you who have succeeded as the victors in the late campaign-not simply on account of the laurels you have won, but rather on account of the qualities, the ability, and the willingness for work by virtue of which you have now succeeded, and which we may be sure augur well for future success. Let me hold before you the example-the living and bright example-of him who has long carried the palm not only in surgery, but in the esteem and affection of the members of the profession, and who was the most distinguished prize winner of his own and probably of any other time; and let me apply to each of you the sentiment of the great poet of old--

Macte novî virtute, puer : sic itur ad astra,

with the remark that you must ascend to greater and greater heights by a continuance of the means which have carried you thus far, and must ever have the ambition to add yourselves to the bright lights which already shine in the firmament of St. Thomas's.

To you, gentlemen, who entered the lists and did not win, I would apply the words of the far-sighted great Cardinal of France, "Never say fail." In proportion as you tried well, so did you not fail, for good work is never a failure, but even bears its own success with it. To have made a good fight, especially on such a field, to have fought and lost, is far better than never to have fought at all. Indeed, it may be said that to lose is sometimes better than to win, forasmuch as it tells of the weak points in one's harness, and stimulates to strengthen and repair them; and if you have come out of the fight with good kindly feeling towards the winners, with increased capacity and willingness to rejoice with them that do rejoice, then, indeed, are you sincerely to be congratulated on the greatest of victories - the victory over those quiet ranklings of jealousy which are the insidious underminers of so much happiness and good feeling, and to which the struggle of life in our profession renders us certainly not less liable than those who are moving in other walks of life.

And surely I may congratulate all of you upon entering into a profession which teems with interest, the work of which is to investigate the forces and phenomena in the various realms of Nature, and bring them to bear upon the improvement of the highest of Nature's products - the human body. I well remember the new life of joy that opened upon me when, at the age of 16, I passed from the drudgery of Latin and Greek and the other ordinary school subjects to the study of the elementary facts and theories of physics and chemistry in the surgery of a medical man, and felt the glowing light of natural science dawn upon me, and realised the glorious liberty of walking in that light and applying the knowledge gained through it to the practice of medicine and surgery; and as I went the other day to the Naval Exhibition at Chelsea and witnessed the marvellous inventions there shown for destruction and the representations of slaughter, the dead and the dying, and the scene of the great admiral in the dim lantern light of the little cockpit, with those around mourning the fatal shot that was carrying off England's greatest hero, I could not but feel thankful to have belonged to the profession the whole work of which is to apply science to a preservation rather than to the destruction of life and limb. It is no small thing, gentlemen, to be entering a profession of such stirring interest and such far-reaching beneficence; and you are entering it at a time when the interest of it is greater than ever, and when the prospects of its future scientific and practical extension and proportionate beneficence seem to be unlimited. The advance in the half-century of my own time, in this Victorian era, has been unprecedented and enormous. The chariot wheels of change have rolled furiously along, travelling over more ground than had been measured in cen- 
turies before, and whirling us through new facts and theories till we are almost lost in the multitude of experiences and blinded with the flashings of new discoveries. At the time when I began, anesthetics and antiseptics had not been dreamt of, there were no excisions of joints, no abdominal operations, and a host of proceedings which are now of every. day occurrence were unknown. It was an antediluvian period without temperature thermometers, without ophthalmoscopes and aspirators, without iodide of potassium, cod-liver oil, or salicylic acid-one might almost say without microscopes or knowledge of minute anatomy, or any but the rudest physiology; and the treatment of wounds was still one of the great opprobria of our practic(e. If in the past half-century we have advanced with such ever-increasing railway speed, what will be the state of things when you take the retrospect of the half-century now berinning, which holds out such enticing prospects in hacteriology. the application of electricity, and other ways: I cannot but envy you the prospect of witnessing the realisation of these ailvantages which we dream of, and still more if it be-as it must he with some of you-your privilege to assist in that realisation.

All this is mattor of special congratulation to you, forasmuch as it ofliers such opportunities for the gratifying that love of knowlenge which is one of the special attributes of man, and which is one of the great sources of his enjoyment and happiness. No human being is without that love; it is the heritage of ('veryone; and, damped though it be by school routine and examination dread, it cannot be quite ki)led. It has its roots lirm in the hreast of each one of you, and will grow up into a goodly fruit-bearing plant if you nourish and nurture it fairly. The food which it reguires and upon which it flourishes best is fresh knowledge. Every acquisition of knowledge incroases our enjoyment, and increases also the capacity and the desire to get more. I thing well learnt is a joy for ever, and opens up fresh sources of greater joy which happily are inexliaustible. Advance as we will, a new ind wider and more charming region is ever before us. As in the starry heavens the highest powers of the telescope reveal a wider rxpanse for still hirher powers to explore, so with the greatest knowledge of the things which serm the simplest there is probally a greater unknown still to occoupy us, and the pride of knowledere must ever be curbed, while the love of it is intensified, hy the consciousness that the ultimate of anything (an never be reached. We need not fear to draw deeply and fully from the wells of science, for they never can be exhausted, and in all the coming ages of man there will still be a vast unkmown to stimulate his thoughts and to fortify his hopes.

One of the important changes in medical study which have taken place in the half-century of my time is increase of ac.curacy in recording, associated with the greater refinements of chemical analysis and the use of the microscope and other 'scopes, of the clinic'al thermometer, the experimental work in the laboratories, and the more careful records of cases, of postmortem appearances, 'tc. It is by aceuracy that almost all great and rood work is done. Accurate work is good work, and inaceurate work is bad work. Aceuracy, bear in mind, is but another word for attention and painstaking. ("pon these' two are reared the edifice of talent and suceess. Falent, as has been well observed, is the farilty of painstaking, and that education alone is good education whatever may liave been the medium employed, whether classics, mathematics, or any other which cultivates attention and painstaking. 'This applies to all the walks of life. Felson won his battles becranse he was a serious, careful, attentive, most painstaking student of naval tactics. Wellington gained his vietories because he gave great attention to the details, small and ureat, of his campaigns. All great orators, from lemosthenes downwards, have taken great pains in preparing their speeches. 111 great operators $-h y$ great operators I mean successful operatorsconsider beforehand the plan of their operations, the instruments they will require, the difficultie's they are likely to encounter, and the means they will employ to meet them. They sketch in their mind's eye or on paper the stages of the proceeding and the attendant possibilities, just as Nelson sketched the line of action he proposed to follow, and which he carried out, at Trafalgar before the battle commenced. Such men have that well-grounded confidence which prevents nervousness. Nervousness, be assureci, whether in operation or examination, indicates want of attention. want of preparation, and consequent want of knowledge. You may dispute this, you may say that you cannot help being nervous, that you cannot always command your attention, that you are liable to be distracted; but remember this is chietly, to a large extent at any rate, because you have not been in the habit of commanding your attention, have not exercised the practice of controlling and exacting oledience from your mental faculties, because you have not taken pains to train your mental batteries to converge well and quickly upon the required point: in short, because the training of that faculty upon which what goes by the name of talent essentially depends, has not been cultivated in you. Do not therefore confess to nervousness. Certainly do not make it to yourselves or others an ex'use for imperfection, but strive to prevent it: and you will best overcome it hy acquiring that knowledge which gives confidence.

Thoughtful painstaking is one of the coördinates with intolligence. A bird will build its nest without it, but it is quite certain that you cannot do the like for yourselves. Our bodies are not intended to be mere automata, but are ('alculated to serve high purpose under the controlling influences. of intelligent will. There must be the will, and where the. will is the way will develop itself. 'To those who have the faith of strong will and determination the mountains of difficulty are removed and cast into the sea. They look large. before you, and they are large. It is best for you to feel that, they are so, and to ench generation of students they are larger than they were to their predecissors. 'The steeps of knowledge to be climbed and the examination portals to be passed are ever on the increase. They have increased not a little during the half-century that I have spoken of ; and I must confess to the feeling that were I now an occupicr of the benches befor' me I should look ahead with some dismay. and I wonder whether I should have the determinate will to make these many mountains remove. IIowever, we may assume that the means and facilities for overcoming the difficulties have increased in like proportion to the difficulties themselves. As the mountains have enlarged the provisions for sealing, for tunnelling, and for removing them have been multiplied. Books lave been adapted and teaching has been systematised; museums have heen enlarged, laboratories have been instituted, and clinical work organised. The harvest is ready, and it is for you to go and reap and gather in.

The great point is so to gather in information as to keep it in. With all the advantages that surround you, you can scarcely help gathering in enough. It forces itself upon you and soaks into you from all directions in a school like this; but if your minds be like the leaking eisterns of the l)anaids, you will leave St. Thomas's llnspital with them little more tilled than when you cintered. How is this fatal leakage to be prevented? I can make only one or two suggestions. In the. first place, be brisk and intent upon what you are about. Cultivate that liabit, and it will require no small effort unless you have already done so. It is not so much the time spent about your work as the manner in which it is spent. (Ine man will learn in an hour as much as another in a week. You are nometimes surprised at the amount which an apparently idle man has contrived to acquire. He has done it because when at work he was not idle, but made brisk use of his time; lie was intent on that upon which he was engaged. You may dissect the hody half-a-dozen times over and not know so much about it as another who his gone over it only once. You may have dawdled round the wards for the three appointed years and have received certificates of diligent attendance witlout being able to recognise the simplest cases of disease, because (it is an expressive phase) you were not at any time "all there." lresent in the body you may have been, but that will have availed little if you were absent in spirit. You must be earnest and hearty in your work, giving your whole man to it if you are to make progress in it. It is easy enourh to judge whether the student is doing this and is in the habit of doing it ; and the good examiner quickly appreciates this, and thus "take's stock," as it is said, of the candidate. In after-life you will find it is the medical man who impresses his patients by his intentness in tho investigation of their cases, and the consequent well-founde: decision of his remarks, who gains their confidence. They 
are quick to recognise the keenness of eye which is the invariable associate of keenness of attention.

Do not take shelter under the excuse that you have a bad memory. That will not avail you. On the contrary, take care not to be guilty of having a bad memory, for memory, like most mental qualities, is to a considerable extent under your own control. It consists, in the first place, in sharpness of impression, which is to be effected by intentness on what you are about; and secondly, it depends on the ability to recreate or recall the impression at the right time, which is dependent upon the activity of the mental effort. Good memory, therefore, resolves itself into attention and briskness-attention in receiving impressions and briskness in recalling them. Most persons can remember what they are interested in because they give attention to it. A great aid to memory is the repeating what has been learnt, whereby the impressions are resiamped and facility in recalling them is acquired. For instance, each day when returning to the dissecting room run over in your memory the part you have already finished. Do not let the work of yesterday slip away under the pressure of that which has to be learned to-day, or you will be much in the case of the Danaïds I have already referred to. I do not think much note-taking at lecture is good. Make some notes afterwards if you please, and examine yourselves from time to time upon them. The very best clinical lesson is the writing out, from memory, in the evening-or, better, next day-the particulars of the cases (or some of them) which you have seen to-day. Nothing so well as this will teach you to observe cases thoroughly, and to observe them so as to remember them, for when you come to write them out you will be reminded of the deficiencies in your observations and the need of more exact and methodical attention in future.

It, is, however, not the mere gathering in of information, the loading of your brains with facts, that must content you. The facts are stored there for the purpose of being used, of being reflected on, and appropriated as required. Thought should be the fellow-worker with observation. The chief use of a fact is as a peg to hang a thought on, and a certain amount of theory is the spice which gives flavour to the dish, the cement which holds the materials in an available and useful form. Theories, it is true, come, and theories go, but as they pass they give stimulus and zest to our thoughts, sharpen our observation of facts, and give impulse to fresh investigation. How signally true has this been of the evolution theory, and whether it proved to be ultimately correct or not, that which raised Newton, Darwin, and Hunter above the level of ordinary men, and made each so great a force in advancing science and thought, was the combination in each of unusual thinking or reflecting power with that of careful observation. How much easier is it to remember a certain number of facts if they are strung together by some little process of thought, and how much better is this than the rather disreputable resort to "tips." If a limb assumes a given position when dislocated in a given way, how infinitely better is it to apply your anatomical knowledge in explanation of the position, than simply and thoughtlessly to learn the symptoms by rote; how much more certain will you be in your diagnosis, and how much more likely will you be to recognise and account for those deviations from the ordinary course of things which sometimes occur, and which cause our chief difliculties in practice.

Above all, be gentle, tender, kind to patients, to the poor no less than to those who are in better circumstances. Never give pain with finger, tongue, or manner if you can avoid it. It is, of course, often necessary to give pain, and then it should be done determinedly and forewarnedly, but it should not be done thoughtlessly. In order to avoid it, and indeed as the best method of examining a case, use your eyes well in the first instance. In order to inculcate this, I am in the habit of cultivating what I call " eye diagnosis" in my pupils. $I$ ask them to tell me, or to tell me approximately, what the nature of the case is by eye observation, to ascertain, that is, as much as possible, and form some opinion in this way. I then allow them to touch or handle so as not to give pain, and lastly, to ask a few questions which should have a definite purpose, and indicate the line of thought as to the case. My motto often repeated, and which is probably familiar to some of you, is, "Eyes first and much, fingers next and less, tongue last and least." The importance of this method was much impressed upon me by observing, as an examiner at the College of Surgeons, how repeatedly the candidates mistook the cases for want of it. They began fingering and ask ing questions of the patients by which, especially as they could not well know what questions to ask, they were usually misled; and they were not set right till I said "Now, quietly look at the case without touching or talking, and you will probably soon see what is the nature of it." This is the method which a good practical physician or surgeon naturally adopts, so naturally that it scarcely occurs to him to suggest it to his students; but if $I$ have succeeded in impressing it upon any of you, if I have caused you to look at the cases well, to glean all that you can with your eyes before you apply your hands, and before you ask questions, I feel that I shall have done you some service. Do not be in a hurry; do not fancy you can jump to conclusions; do not think what you have to do is easy, or you do not do it well because you will not take pains about it. It is not easy to do anything well.

I will trouble you with only one further remark. I have said that the love of knowledge is natural to man. I may add that so also, happily, is the love of good. It, like that of knowledge, is inherent and deep-rooted in the liuman breast, and cannot be quite extinguished. There is no man who does not naturally prefer good to evil and who does not prefer good people to bad people. Many things choke and seem to blot out this feeling. but there it still ever is. To be without it would be the realisation of what we mean when we speak of " devilish." To cultivate it is, of course, more important even than to cultivate the love of knowledge; and this is best done by recognising, and heeding, and rejoicing in the good points in others rather than their bad points. We all like good-hearted persons. We all desire to be esteemed goodhearted and to be good-hearted. We know that good-heartedness will cover a multitude of deficiencies. Its most marked feature is that it takes a favourable kindly view of others, especially of their failings; and each one of you will find that he is advancing towards this desirable character, and is growing in the esteem and affection of his fellow students and of all who know him, as well as in self-respect and happiness, in proportion as he inclines to appreciate the good qualities of others, and to make allowance for their shortcomings, and to be not severe to mark what they have done amiss. To the great motto " Evil be to him who evil thinks" may we add as its more important corollary "Good will be to him who good doth think."

Gentlemen, my best wish to you is that you may deserve success and happiness in your life's career, being assured that, if you do deserve them, there is no profession more likely to yield them than the one upon which you are entering.

\section{A B S T R A C T S.}

\section{MIDDLESEX HOSPITAL.}

On Thoroughness.

The Introductory Address was delivered by William DonCAN, M.D., F.R.C.S., Obstetric Physician and Lecturer to the Hospital. After some preliminary observations, he went on to say: In thinking over this address, how best I could tell you something useful, something helpful to you in your studies, and for your future work in the practice of your profession, I recalled my own student days, remembered the difficulties I encountered at starting, and, later on, mistakes made and time lost by ill-directed work, so it occurred to me that some hints from my own experience might perhaps be the most valuable things I could tell you.

To begin at the beginning-for, as I shall often remark and insist upon, method and order must ever guide your work in each and every detail-the first obstacle which usually confronts those seeking to enter the medical profession is the Preliminary Examination. Let me earnestly advise all new students who have not passed the Matriculation Fxamination of the Iondon University to do so without delay; once you have passed this and the Preliminary Scientific (which is really not difficult), the rest is plain sailing, and any man of 
ordinary ability will find it practically as easy to obtain the M.B.London as to get the double qualification of the Royal Colleges of Physicians and Surgeons.

A new era is now opening for the London medical student by the formation of the Albert University, and those of you who began your studies without matriculating are to be congratulated in that, instead of spending the two last and most valuable years of your curriculum elsewhere in order to get the degree and title of Doctor of Medicine, you can now spend the whole time in London, which possesses the largest amount of material for clinical teaching in the world, and at the end of your studies you can go forth as fully equipped as your fellows to compete in the keen struggle for existence which goes on in the medical as in every other profession. At the same time, gentlemen, remember that the degree of the Albert University, whilst conferring on you the coveted title of " I)r." cannot and will not carry with it the same high reputation for depth of professional knowledge which is so justly accorded to the degrees of the London University; therefore, as your object in this as in all other things should be thoroughness, I must reiterate my advice to you to matriculate.

The object of a course of study in medicine is not only to make you acquainted with a number of facts, but to train your minds to estimate accurately the relative values of these facts in their bearing on each individual case brought before you -in short, you have to learn the art of reasoning. Two things are essential-namely, the full knowledge of your work in all its details, and a mind properly trained to grasp the whole as well as to see each part in logical order and position. No mere parrot learning of your work will effect this. System and method must go hand-in-hand with accumulation of facts, and the earlier in your work you realise this the hetter for you. It is this which gives the special value to a course of university training as a preliminary to the study of medicine. Amongst other things, the Greek and Latin, which are now undervalued by some, are capital aids to the training of the reasoning powers, and he is to be congratulated who has learnt something of logic before commencing his medical work; but even if you have not had these advantages you can make your ordinary course in a great measure supply the deficiency, and be the means of training you to see clearly and appreciate correctly.

The student, having passed his preliminary examination, is ready in the first winter $s$ ssion for the study of anatomy and physiology. These subjects constitute the solid foundation on which is built the study of medicine, and I cannot too strongly and carnestly advise you to master them thoroughly. Here the student who has some knowledge of comparative anatomy will find it much to his advantage.

Until the first professional examination is passed (or at all events until after the first year) you must (carefully avoid going into the out-patient rooms or the wards, as you learn practically nothing, and only get in the way of the senior students. Your proper place is the dissecting room and the physiological laboratory. On the other hand, be assiduous from the very beginning in your attendance in the operating theatre, so that you may see as many operations as possible. With regard to lectures, my own opinion is that there are far tor many given, unless you will (as I fear so few of you do) take full notes of them. You can make your lectures invaluable to you, and it is not at all difficult to put down every fact stated by the lecturer; a little practice will enable you to do this with facility, and it is a capital training for writing examination papers. Those notes are the groundwork of the subject lectured upon; they contain in a short space nearly everything you want to know, and you can read them over and over again many times in a shorter period than it would take to read a book on the same subject. Besides this, they keep your attention fixed much better than reading a book, as the words recall what you saw as well as heard at the lecture. A student who has a full set of notes on each subject of his examination has an immense advantage-in fact, he feels a sense of security which can hardly be gained by simple reading. But you must supplement your notes by reading books. You will always find your teachers ready and eager to tell you the best book to read on each subject, and, when you have the book, make up your mind to digest it thoroughly. My plan was to make an abstract of each book I read written in ink in a good-sized notebook; and it is surprising how quickly you can do this, and how small a space it takes up, especially if you arrange the facts in order under their proper headings, leaving a margin at the side for this purpose. Wherever you can, arrange the data in tabular form ; it is simpler, clearer, and more easily seen and read. When once you have made an abstract of a book in this way, if properly done, you need never look at the book again, or only for reference. This is an excellent training in the power of condensing expressions - a most valuable acquisition, as you will find when you come to write an examination paper. Reading, too, is much more interesting when done in this way; after a time the process of epitomising becomes absolulely fascinating. An orderly and methodical habit of writing will teach you to think in a similar fashion, which is one of the qualities most needed in our profession. It is a capital plan to supplement your notes of lectures from books. For example, in notes of lectures on medicine (and senior students well know of what exceptional value are the lectures on that subject given in this theatre), when you read some work on the same subject, have your lecture notes before you, and add any facts mentioned in the book which you do not happen to have down in your notes. I usually kept one side of the notebook for this purpose, and interpolated matter from several sources on the opposite page. This may often take the place of making a complete abstract of the book, and in one notebook you have the contents not only of a course of lectures, but also of several works on the same subject.

I cannot too strongly warn you against what is known as "cramming" by so-called "aids," and similar imaginary short cuts to knowledge. Speaking as an examiner, I know that examinations tend more and more in the direction of ascertaining how you have been trained, and not merely to find out how many things you have learnt. If anatomy and physiology are the groundwork and basis of medicine, pathology is its chief substance and support. As dissections and practical physiology are to the junior student, so are pathology and morbid anatomy to the senior.

In the hospital wards and out-patient rooms you will have opportunity in clinical work to make use of the facts you learn in your lectures and textbooks. In examining patients you must use the same method and order which I have described to you. By this means "case taking," as it is called, will prove of the utmost value to you, and your notes of cases will be valuable to the physicians and surgeons in charge. Most of the mistakes made in diagnosis come from inaccurate and imperfect examination. The most fatal mistake of all is to let the habit grow upon you of carelessness in your work. it is a greater bar to success in your career than any other. The best way to avoid it is from the first to be methodical; have a clear, well defined rule to go by, and follow it out to the end. Devote a certain number of hours daily not too many) to study, apportion definite hours to each subject, and adhere as closely as possible to your scheme. Those of you who can study in the early morning will find it of the greatest value, for at that time your brain is unwearied from the day's work, and there is nothing to distract your attention. Three or four hours' study then are of more value, I am confident, than double the number late in the day. All my reading as a student was done between five and nine in the morning. Students often make the great mistake of leaving some branches of their work almost neglected, and begin practice with little or no practical knowledge of special departments. Attendance in the special departments and a thorough practical acquaintance with them will give a sense of security to you when you enter practice, which cannot possibly be obtained by mere theoretical knowledge. It will save you years of toilsome and anxious striving to acquire a facility which a few month' work here would have ensured you. Now that there are to be five (all too short) years of medical study, let the last year be devoted in great part to this, and if you can spare an extra year after your studies are completed and your final examinations passed, it will be a year most wisely and profitably spent.

Speaking for my own special department (obstetric medicine and the diseases peculiar to women), I feel that it is, perhaps, the most important of all, for it is probably the first in which your knowledge and skill will be tested after you have started in practice, and the happiness of many households 
will depend on how you have during your hospital career taken advantage of the opportunities afforded you of becoming well acquainted with the subject.

The maintenance of health is your work, and to do it effectively you must be healthy yourselves physically as well as mentally. Do not, therefore, neglect the training of your muscles during your course of study. It is a capital thing for a man to have some individual hobby or means of recreation for his spare time apart from, though it may be more or less associated with, his daily work. The present is a stirring time in the work of medicine. New scientific discoveries have revolutionised the theoretical part, and with the change in theory practice varies also.

[Dr. Duncan then gave a sketch of the great advances made in the domain of operative surgery. paying a warm tribute to Sir Joseph Lister, whose teaching had made them possible. In medicine the subject which had excited most attention had been Koch's treatment of tuberculosis, which, though falling far short of the expectations raised by its announcement, would probably prove of some use, and at any rate indicated that research was taking the right direction. Pasteur's treatment of hydrophobia proved the immense importance of the study of bacteriology. and Dr. Duncan asked if there ought not to be a national institute for the thorough investigation of the subject. He went on to show how strict antisepticism in midwifery had diminished the mortality from puerperal fever, quoting the statistics on the subject brought before the recent (Congress of Hygiene by Dr. Priestley.] He then proceeded as follows :- I have indicated to the best of my ability some of the means whereby you may study to advantage, hoping to enable you to work upon a sure foundation. It is for you yourselves to raise the edifice by steady, honest, and (nithusiastic work. Your studies are by no means completed when your curriculum is at an end. There is no standing still in a calling where advance is perpetual without falling out of the ranks.

Aim high, gentlemen : remember always in all your actions to be worthy of your profession : keeping ever to the straight path of rectitude and honour. In the present day when the ranks of every profession are overstocked there is, and necessarily must be keen competition. But this should stimulate you all the more to have a good start in the race, not to be content with mere mediocrity or, still less, to just scrave through your examinations. It is within the power of each one of you to make a mark for himself, however many and great may alpear the obstacles in the way. But it can only be done by steady application to work; well-regulated, methodical, purposive work during the years of your curriculum. Bring to your work a due sense of its importance. Remember that you are striving to fit yourselves for dealing with the greatest prollem of all - the problem of life. Whatever difficulties and disappointments may meet you in your life-work, whatever the hardships and trials of a doctor's life, you will have much to recompense you in the knowledge that your work is at any rate one useful to mankind, and, if rightly followed, ennobling to yourselves.

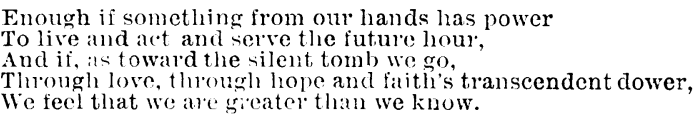

WESTMINSTER HOSPITAL.

The Trainisg l'reparatory to Mentcal Śtudy.

The Introductory Address was delivered by WALTER $G$. Spexcen, M.s., M. B.. F.R.C.S., Assistant Surgeon to the Hospital, who cormmenced with a short account of the history of medicine. He then said: Let us now consider some of the subjects which, it is generally conceded, ought to be within the grasp of every member of the profession. Latin and Greek were formerly a necessity to every well-educated physician, when medicine depended upon authority, and the treatment of a case upon quotations from writings in those languages. They are now termed dead, killed by the aid of schoolmasters who have persisted in teaching them from the wrong end, namely, from the grammar. After struggling through grammar a boy has to take up prose composition, so that the majority are utterly wearied and choked off before ever they arrive at the essential stage of being able to read a Latin or Greek author. What an extraordinary amount of time is spent with only very slight result: It is proposed to substitute French and German, but many masters attempt to insert the old leaven by commencing with the grammar; and with the same result, that years are spent without boys being able to converse or read a simple book. Did grammar, then, exist before language? How do children learn their own? If a man wishes to learn any foreign language, will he not read through a book in that toncue along with its English translation? Will he not learn to speak from one conversant with the language, and make much progress before ever he troubles himself about the finishing touches of grammar?

French and German differ widely in their usefulness. Our own language can only be improved by reading the best French authors, which lose their most valuable characteristics in a translation: and besides, there is the use of French as a conversational medium. and the interest of good novels. In German there is nothing which cannot be as well expressed in a translation, and an extensive reading of German, especially of scientific works, has a tendency to injure our English, as may be seen in many medical writings of to-day. But Germany is full of living encyclopredias. Taking any subject, you may be quite sure that within the last year or two some book has been written in that language, which contains almost all that can be said, as well as a list of previous writers from whom information has been collected.

School is not the place for any extensive study of science. The so-called science of common thinss, taught with plenty of illustration and demonstration, is sure to do good by leading boys to develop their powers of observation. But even among these small efforts some are wrongheaded in the extreme. For instance, a master will propose to teach elementary comparative anatomy and physiology, and will start with the primer written by Professor Foster. In spite of the statement at the commencement, that it is impossible to begin this study without the organs of a rabbit or the heart of a sheep, the boys are made to learn page after page simply by rote. I know a school where Gill's Chemistry had to be learnt through without any experiments whatever.

It is proposed to extend the compulsory medical curriculum to five years. The first of these should be occupied by scientific subjects-zoology and botany, chemistry and physics-as is the case now at the universities. The study of botany has undergone many changes since the time when the physician had to gather and prepare his own drugs. We have in the practical botany of to-day a course most suitable for obtaining an acquaintance with microscopic objects and for commencing the study of vital processes. The study of the anatomy of creatures simpler in their structure is the proper way of approaching the difficulties of human anatomy. At the present time all the non-university men commence a scientific education with lectures on the circulation and human bones, and many take six months before they begin to grasp the meaning of the words which fall on their unaccustomed ears and to accommodate themselves to the new methods of learning, while it takes them about half the course of histology to see objects clearly under the microscope. Of equal, or of more urgent, importance is a preliminary knowledge, not only of inorsanic, but of organic, chemistry. Now a non-university student has to learn about the chemical composition of the blood and the changes occurring along with coagulation within six months of starting science. In the absence of any knowledge of organic chemistry, physiological chemistry becomes simply a question of committing certain words to memory : but, beyond this, there are the problems of pathological chemistry. It is from chemistry that medicine looks for its future, but what share can a man take in that advance who has not as a student gained even the elements of the subject

I shall hope to see one change in future examinationsnamely, a depreciation in the relative value of the written examination. Now the weaker men must cram or be crammed. A teacher cannot keep such at their practical work at least within three months of an examination. An extension of the examination in practical physiology should not be stopped by the question of expense. If limited to the recognition of histological preparations under the microscope, the student will buy the specimens at a shop. 
Courses of practical physiology have been proposed for general use, but how is a teacher to make a student go thoroughly through such a course if he is not to be tested at the examination? How much more important to be able to estimate the amount of nitrogen in the excreta, to use the ophthalmoscope, or to stain the tubercle bacillus, than to commit to an ephemeral memory condensed sentences and tables of all sorts :

A first year employed in preliminary science allows sufficient time in the next year and a-half for a good acquaintance with human anatomy and physiology; but during this period relief ought to be given by a reorganisation of the subject of materia medica. The chemical and botanical part should be learnt in the preliminary scientific year; the physiological action of drugs is a side-light upon physiology, and should be taken with that subject. Therapeutics is a *inal subject only, not for those who have never been near a -sick bed. Materia medica proper is part of a practical course in pharmacy which should fit a man to dispense medicines to learn less is a waste of time, to learn it at all is a question for decision after qualification, in case it be required by the individual in his practice.

The final examination should deal with general principles and common diseases; therefore some knowledge of forensic medicine, fevers, insanity, and hygiene should be required, whilst rare medical diseases and large surgical operations should be omitted. Common diseases include those of special organs, but imply no particular acquaintance with any so-called speciality. After all, the qualifying examination is a minimal one; to attempt to make it inclusive is absurd.

The important university question I must leave to Sir George Young. I cannot but regret that a majority of my fellow graduates prevented the formation of a pass examination in the present University. It was curious to note how some-whom one had supposed to be Radicals and Democrats-were urgent supporters of privilege, and voted for the transference of power from a department of the Government to a private body.

However, let the future pass examination in the new university be readily accepted; let II.D. be given after the examination at the end of the fifth year, and let M.D.London stand for the degree of both universities. The pass and honours examination can always be distinguished when necessary, as at Oxford and Cambridge.

\section{ST. MARY'S HOSPITAL}

Tire Conditions of Success in the Medical Profession. The Introductory Lecture was delivered by Mr. Henry Juler, Ophthalmic Surgeon to and Lecturer on Ophthalmology at the Hospital. After offering a hearty welcome to the students in the name of his colleagues and himself, he congratulated those who were just entering on their medical career upon the object of their choice; in his opinion, the profession they had chosen was much to be desired above all others. In no other learned profession could there be such freedom of thought, liberty of action, power of doing good to others, and at the same time such certainty of gaining at least a competency for one's labour. Any man who had the ability, and determined to aspire to high honours in medicine, could be assured that nothing but the lack of those qualities could prevent the realisation of his desires. Social position, scientific eminence, professional distinction, and such wealth as usually fell to the lot of successful medical men would all come to him if he would study diligently, observe closely live righteously, and wait patiently for results. On the other hand, the profession of medicine was no bed of roses, and they would do well to realise that fact, either now or before they had passed their final examinations. To the end of their career each one of them was bound to read, mark, learn, and inwardly digest all that was known of the work in hand; and in these days of rapid strides in scientific discovery they must be constantly on the alert, for medicine was based upon the natural sciences, which were for ever moving onwards. A man who did not keep himself in touch with all discoveries bearing upon his work was allowing himself to drift backwards in such a way that he could no longer do his duty by the patients coming under his care. The successful pursuit of medicine required constant energy, perseverance, and enthusiasm, and they would do well to bear these facts in mind before finally deciding to embark on the medicallife. An idle and luxurious man had no place in any corner of the profession, and anyone embracing medicine as a mere moneymaking concern would only meet with bitter disappointment, and would know nothing of the happiness of a true physician; with: such a motive he had better turn his attention to those channels where pecuniary gain constituted the express object of those who entered them. He reminded them, also, that many men entered the ranks who were disqualified from ever attaining to any position of eminence, owing to defective mental and bodily qualities; such persons would do far better to choose some other vocation, where a good personal presence was of less importance. He then referred to certain qualities which were essential to the success of a medical student, placing in the first rank a good constitution, combined with healthy habits of life; athletic sports were strongly recommended during the student life as tending to promote good health, manly and sociable habits, and a knowledge of human nature such as would help them in after-life. Reverses would certainly come to those who aspired to the highest honours, but they were advised to use these as stepping-stones to renewed efforts. Previous education and training-especially in classics, mathematics, English, French and German-were of great assistance; but in addition to these a good practical knowledge of biology, chemistry, and physics was most essential. Those who were not possessed of this knowledge he advised to lose no time in obtaining it, for without it there could be no satisfactory progress. Great importance was laid upon the study of physiology; not only microscopic work, but practical laboratory work was strongly urged. The four years prescribed for the study of medicine were insufficient. Although by careful manipulation of time the examinations might be passed at the end of that period, then was really the time for a new departure in which the more thorough cultivation of study should be carried out; hospital and other appointments where the course of disease could be followed through all its phases should then be taken, and they should be careful not to leave the atmosphere of work until such appointments had been held. In conclusion, Mr. Juler congratulated them on having entered at St. Mary's Hospital during a period when the medical school was in so prosperous a condition, and when it was purposed to devote the proposed new buildings in Praed Street to the development of greater efficiency and facilities in the way of teaching of the various specialities.

\section{ST. GEORGE'S HOSPITAL.}

The Scientific Basis of Medicine.

The Introductory Lecture was delivered by G. Fielning BIANDFORD, M.D. After congratulating his hearers on the improvements which have been made in the hospital and school buildings during the past forty years, the lecturer went on to speak of the changes which have taken place in medicine and medical science during the same period-changes so vast, so marvellous, that they seem almost like the tales of fairyland or magic. They are changes of greater importance to the human race than those produced by railways, or electricity, or the penny post, for they concern the life of man. The cure of disease on the one hand, and the prevention of disease on the other, have made such strides as they never made in a similar period during the world's history. And the origin of all these changes may be found in the researches and experiments of a French chemist, Louis Pasteur. His first investigations were entirely chemi al. Having discovered a particular chemical result by fermentation and an organism produced thereby, he went on to investigate such organisms, and found that fermentations of various kinds were due to them. This knowledge he applied to the fermentations of beer and wine. He took the microscope into the brewery, and showed the brewers and the winemakers why their beer and their wine turned sour. In this way he conferred an inestimable benefit on all engaged in these trades. No less benefit did he confer on the silkgrowers of France. For twelve years the silkworm disease had raged there until the silk industry was brought to the very verge of ruin. Pasteur brought his microscope to the home of the silk- 
worm. Before his arrival they had discovered certain microsccpic corpuscles in the blood and tissues of the diseased caterpillars; but if they could not find them in the eggs they assumed that the latter were healthy. Pasteur proved that unless the moth were healthy the egrs would be worthless. He caused every moth and her eggs to be kept separate. He examined every moth after she had laid her egos with the microscope. If the disease was found in the moth the eggs were burned; if the moth was healthy the eggs were saved. After creat opposition he proved the correctness of his experiments, and the silk industry-which is a matter to France of some millions sterling-was restored.

Not content with all this, he went on to show that not only the silkworm disease, but diseases of higher animalssuch as anthrax, which is also known as "splenic fever" or "wool-sorters' disease" - are due to a microbe or organism which produces a kind of fermentation. And here his researches led him not merely to the discovery of these organisms, but to one of equal importance, namely, the possibility of so attenuating or weakening the virus as to furnish a general method of protective or preventive vaccination.

This brings us back to the origin of all vaccination, to the work of a St. George's man, Edward Jenner. He established the fact that the vaccination by cow-pox prevented small-pox, and by that discovery he has saved millions of human lives. From this isolated discovery Pasteur has generalised the deduction that most, if not all, infectious diseases can be dealt with in the same way. From the cholera of chickens he has advanced to that most horrible of all diseases, rabies or hydrophobia, and has shown that even after a bite protective vaccination will avert the fatal result.

From the investigations of this French chemist, his fermentations and bacilli, his cultivations and inoculations, has sprung all that series of discoveries which come before us every day as antiseptic surgery, as the bacilli of cholera, of pneumonia, of diphtheria, of typhoid, of tuberculosis. Though forty years ago we were familiar with phthisis and tuberculosis, none suspected that the seeds of the disease could be conveyed in the milk that we drink, or the beef that we eat. Yet a congress of European savants engage in a discussion on the dangers of tuberculous food. Others think that the tubercle bacillus is derived from the air by inhalation; and besides this, there is the question of disinfection in the living body, of which so much has been written in connection with Professor Koch's tuberculin. Problems of all kinds are being investigated and debated on every side, and are receiving new light and development day by day. It is an age of transition from which much may be expected. The young who are now commencing their medical career should be greatly stimulated and encouraged by what has been discovered in the last thirty years. They are entering upon a period full of promise full of hope. There never was a time in which one could set forth on the path of medical science with so sure a prospect of reaping a rich reward. For there is now a scientific basis on which the art of medicine can found itself, and which it has long lacked. Old empiricism is foredoomed to give way to something more in the nature of exact science. But besides scientific work, which must be conducted in the chemical or biological laboratory, those who come to a hospital as medical students must study disease in the patients which fill its wards, and the time of the curriculum, even if it be five years, will not be too long for this.

The student must habitually observe and consider the sick and note their appearance when suffering from this or that disorder. He must familiarise himself with the physiognomy of disease, which he will find of service to him all his life. It has been said that a first year's student has no business in the wards, that he must get through a portion of that string of examinations which is expected of him, and then when he is free to forget all his earlier work he can devote himself to clinical pursuits. But a student in his first year has eyes in his head and cars wherewith to hear. He can see whether a patient is completely or incompletely insensible. He can distinguish between the delirium of fever and delirium tremens. He can note the difference between a patient suffering from pneamonia, bronchitis, or phthisis. He cun see the next day whether he is better or worse, whether the disorder is tending to recovery or death. But the student will not long be left to the eye alone. The list of instruments is be- coming a long one. Besides the stethoscope there have been added in these 30 years the all-important clinical thermometer, the ophthalmoscope, the otoscope, the laryngoscope, and the cystoscope. Moreover, there is the spectroscope, and that which nowadays is as important as any, the microscope.

The lecturer concluded by giving the students two pieces of advice. The first was that all should learn and practice drawing. Drawing now is almost a necessity in the study of anatomy, microscopy, or pathology, and he who cannot draw is at a great disadvantage. Not only for the purposes of teaching but for learning and note-taking it is well nigh indispensable. People say they cannot draw. Those who say this have probably never tried. All can write, but writing was not acquired suddenly but by long and painful practice. Drawing will improve the handwriting of those who write badly, for artist almost invariably write good hands. The second was that everyone should have over and above his work some occupation, hobby, or intellectual amusement to which he may turn for relief and distraction after the day's toil is over. For lack of this many suffer greatly if by any chance their daily routine of work is stopped.

LONDON SCHOOL OF MEDICINE FOR WOMEN.

On General Cultere as an Aid to Menical Stuiy. The Introductory Address was delivered by Mrs. Dowson, L.R.C.P.\& S.I., Lecturer on Forensic Medicine and IIygiene. After some introductory remarks she proceeded as follows:-

Amiel, in his journal, says that the principal grievance he has against the dortors is their neglect of the real problem before them, this problem being "the seizing of the unity of the individual." The charge is serious, but is certainly true of some of us, men and women alike, and it is likely to remain true unless we recognise that an essential part of our training lies outside our purely professional curriculum. The object of our training should be that we may see a patient, not as a patchwork of signs and symptoms, but as a human being, an organic whole, of which no part can be understood or treated except with due regard for the interdependence of all parts, and the relation of the whole to surrounding things. This means that we must have some acquaintance with the main principles and generalisations of the special sciences, and with the outcome of philosophical thinking. It means too that we must be within, and not outside, the current of thought generally.

Never were the lines of convergence in the different sciences so plainly marked as at present, and never was it so plainly necessary to know something of everything in order to know much of something. But the very fact of this convergence makes it possible for the student to attain a sound knowledge of what is necessary without neglecting purely professional study and practice. There need be no superficiality; this does not mean a smattering; it is the right way for the student to recognise practically the fundamental oneness of knowledge and of life, and its import for herself and her proper work. She should make up her mind to know, for instance, in each of the sciences, not the small details of either material or method, not all the steps by which its present position has been reached, still less some few of those steps isolated from the rest, but what, in relation to the problems of human life and well-being are the results attained, and what in principle is the method through which they have been established. And it is the duty of everyone "to make life as full a realisation as possible of human capacities ". a duty which does not cease for the student but is rather em phasised when she begins to train herself for a form of service which in its scope and significance is of the greatest.

Among other benefits arising out of the possession of general culture is a mental outlook wide enough to enable us to see famcies of the day and hour in their richt proportion to other things, and to keep us from taking up "fads." And one of the evils fostered by a narrowly technical training is professional bigotry. We should bear in mind that the professional dictum of the moment may be reversed as it has often been reversed before, and that the professional atmosphere sometimes partakes of the nature of fog.

culture, scientific and general, opens the mind to an influx 
of refreshment and strength, to an added interest and a stimulus, which enable us to do our professional work more easily and more intelligently, and to bring to bear upon it the illuminating power of a comprehensive knowledge. We can know nothing rightly if we see it as an isolated fragment, we can make no fact truly ours unless we have assimilated or are assimilating other's by the sicle of which it may be placed. Moreover, we "am never feel the right sort of intellectual confidence, the right self-respect of understanding, unless we have at least in intelligent appreciation of the bearing upon our own work of work that is not ours. If we ignore these facts we make it possible for thinking men to say, as Amiel did of doctors generally, that we neglect the real problem before us-the truth being that we have put out of reach the power of seeing what that problem really is. The best students apparently do not feel tempted to an exclusive devotion to purely technical work; their minds are open in every direction. And we must all endeavour, here as ever, to follow the best, that we may fit ourselve's so far as may be-as good doctors always fit themselves - for seeing our patients as they really are, whole human beings, having a physical aspect and a psychical aspect, and standing in a relation affecting them in both aspects and in every part, with a whole universe of men and things.

\section{SIIFFFIELD SOHOOL OF MEDICINE.}

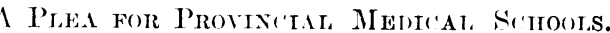

THe Introductory Address was delivered by Mr. W. F. Favert, Senior surgeon, Sheflield General Infirmary and lecturer on Surgery, sheffield School of Medicine. After a few words of introduction, he said he could hardly help contrasting the present condition and equipment of the Sheflield School of Medicine with its condition when he was a student, forty years ago, nor could he help sincerely congratulating those who were artively engaged in teaching now on the satisfactory and (neouraging state of the new School of Medicine. Not only wore they numerically stronger as regards students than thry had ever been before, but the teaching staff had been strengthened by the addition of able and enthusiastic young men, and they had endeavoured by administrative changes in the conduct of the school to still further interest all workers in its efliciency and success, whilst their connection with Firth College had enabled them to get most valuable help in scientific teaching from some of its distinguished professors.

The speaker then referred, in graceful terms, to those who had been engaged in teaching during his own student days Dr. De Bartolomí, I)r. Elam, Mr. Samuel Gregory, Mr. William Skinner, Mr. Jonathan Barber, and others who were almost forgotten now. One name he (Mr. Favell) could never forget, that of the late Henry Jackson, the father of his valued friend and colleague, Arthur Jackson, and formerly surgeon to the infirmary, and lecturer on clinical surgery.

It was pleasant to see in the very able and active working staff of the present School of Medicine, the names of the sons of some of those men who did such good work in the old school. The teachers of the present day had infinitely better and more commodious premises in which to carry on the work of medical education than those who preceded them ; it was impossible to go on longer with the confined span of the old school. It had had its day, and done good work, but a new school was necessary, if they were to comply with the requirements of the present day.

But (continued Mr. Favell) it may be asked, Is it a good thing to have provincial medical schools? Are they worth supporting, and do they work well for the public and the medical profession: I know the question has been raised before now and I know that some have no warm feeling towards provincial schools. The arguments against supporting them. I imagine. would be that the teachers holding chairs in the great metropolitan schools are men of acknowledged eminence in their: profession, that the field for clinical teaching is an enormous one, that the equipment of metropolitan schlools in the way of museums, preparations, plates, physiological and electric apparatus, and all the ac, plates, necessary for the highest kind of medical teaching, are as perfect as can be, and that students who enter at a metropolitan school have advantages which a provincial school can- not command. Well, for the sake of argument, let us grant this, but just let us consider for a moment the arguments in favour of provincial medical schools, and I think you will agree with me that in some respects provincial schools possess advantages which the large metropolitan schools cannot ofler.

First of all, in a large manufacturing town like Sheffield, with its crowded population and numerous factories and workshops, where diseases of various kinds are engendered and where accidents are constantly occurring, we have enormous material for teaching, and a field for clinical observation and work the value of which cannot be overestimated, and which it seems almost a sin not to utilise for teaching purposes. With the ability, the enthusiasm, and the love of work which I know we have in many of the lecturers connected with our medical school, we have here the most important requisites for imparting to our students a thoroughly sound, practical, and scientific training. Moreover, I think it is a fact of no small importance that in a comparatively small school such as ours-small in comparison with the large London schools - the students are necessarily brought into closer personal contact with their teachers than can be the case in a school numbering its students by hundreds. I believe that in this way the student at a provincial school has a chance of more thorougl and practical grounding in his work, of more constant and close personal communication with the lecturers and teachers, and more opportunity for that close observation of the nature and treatment of injuries and diseases, which is the most valuable practical part of a medical education. We all know that a young man blessed with a retentive memory and a fair amount of assurance may, by hard reading, careful dissecting, and little else, be enabled to pass a brilliant examination, and still, I hold, be unfit to have the lives of his suffering fellow creatures committed to his care. A man may be thoroughly well read, he may be crammed full of book learning, he may be a master of the scientific side of his profession, but if he has not had the opportunity of practical acquaintance with disease and injury under the supervision of a competent master he will find himself at sea when he begins the practice of his profession.

I often feel almost appalled when I think of the immense responsibilities which rest on the shoulders of the medical man. What a power for good he may be if he possesses the requisite practical knowledge of his work and a conscientious determination to do his duty! And what a power for evil he may be if he dares to face his responsibilities without that practical training which is so absolutely necessary for the safe and successful and satisfactory discharge of the obligations he has incurred! And I cannot too strongly emphasise my conviction that before any young man receives a diploma authorising him to practise he ought to be compelled to produce evidence of having-in addition to the ordinary curriculum of study required by the Licensing Boards-spent twelve months in the careful study of disease at the bedside of the patient, under the supervision and guidance of an experienced and competent medical man.

But let me urge one other point in favour of provincial schools. I contend that not only are they valuable as giving facilities for a sound practical and scientific training to the coming medical man, but they are of no small value to the community in which they exist-and this in more ways than one.

In the first place, they give the chance and opportunity of entering upon their medical studies to young men who have just left school without the necessity of taking them away from home discipline and home influence, which are of inestimable value to youths just entering upon manhood, and the loss of which in early life has been the ruin of many a one. Far be it from me to say that the majority of young men have not self-respect enough and sufficient sense of what is right to avoid the temptations to which they will be exposed when home influence is suddenly removed from them. But it is not so with everyone, and to all it must be a great boon at so impressionable a period of life when facilities for medical study can be combined with the healty discipline and judicious influence of home life.

Only one other reason will I trouble you with why I think provincial schools are a benefit both to the profession and to 
the community in which they exist, and that is that they guarantee to the public the existence of a staff of medical men who must keep well abreast with the discoveries and advances in medical and surgical science and practice which are constantly taking place. A physician or surgeon who has undertaken the responsibility of teaching the educated and intelligent class of young men who in these days present themselves at the medical schools cannot go to sleep over it. The existence of a medical school in our midst necessitates also the existence of a staff of careful, vigilant, and observant medical men, always alert to mark any change in practice, any alteration, improvement, or invention which a ceaseless spirit of inquiry and investigation may elicit. Surely, then, a medical school in our town is good for the profession and good for the public.

Mr. Favell concluded with a few words of encouragement and advice to those about to enter on their medical studies. The five y'ars' curriculum, which would shortly come into force, was not, in his opinion, at all too long a period of training when the number and extent of the subjects to be acquired, and the immense responsibilities of the medical profession, were taken into account. If the curriculum extended over fifty and five years instead of only five they would still find how much they had to learn. The medical man was a student all his life, and he would be astonished at the close of his career to find how little he knew, and how much he had had to learn and unlearn again during the progress of his life's work. Mr. Favell dwelt particularly on the study of psychological medicine. The requirements of the new Lunacy Act made it imperative on the general practitioner to have a very definite knowledge of lunacy. He said that by patience, by strict attention to work, and by rectitude of conduct, it was open to all of them, if not to amass riches, at all events to make a competence, and to occupy a trusted and honoured position in the community in which their work was carried on ; but he earnestly begged of them not to let impatience of success lead them to adopt unworthy means to secure it, nor to attempt to raise their own reputation at the expense of that of a medical brother. You know, he went on. how nervous and morbidly sensitive long illness makes not only the sufferer, but those who, with a most painful anxiety, are watching him day by day, and how even an insinuation or a half-expressed doubt may undermine confidence, and result in the loss of practice. We are all of us very fallible; we are all apt to make mistakes, and instead of taking advantage of the mistake of a brother we ought to do all in our power to help him out of a difficulty, and restore his comfort and confidence. Do not forget that golden rule, "To do unto others as you would they should do unto you.' Let me also beg of you young men about to commence practice not to resort to the reprehensible, though more open method, of advertising your skill, or allowing well-meaning but injudicious friends to do it for you. Depend upon it, such unworthy means do not succeed in the long run. You may gain some temporary success, you may impose upon the credulous, but it is only by honest work, honourable conduct, and a conscientious determination to do what is right, that you will success to your own satisfaction, or secure the confidence of those whose good opinion you most highly value. And in the early months, or first year or two of practice you may find a difficulty in your relation to your patients-perhaps from want of conficence in yourself, perhaps partly from youthfulness (of which you will mend every day) you may fail to gain the confidence of your patients in such degree as you could wish; but do not be discouraged at this-it is what all young men have to put up with; but I will tell you what I believe will help you to attain this object more certainly than anything else, and that is to cultivate a spirit of true and genuine sympathy. I am afraid many young men in strong and vigorous health are not very sympathetic. I must confess that, in my long experience, I have seen one or two young house-surgeons get into the way, from routine and habit, of looking upon patients who presented themselves at the hospital as simply "cases," and treating them almost as if they were pieces of machinery, and were not endowed with the ordinary feelings and sensations of human beings. Now let me beg of you never to let familiarity with suffering blunt your feeling of sympathy with the sufferer. To every rightminded man, to everyone who has a heart to feel and an intellect to think, distress and suffering accentuate and intensify sympathy; and you will find that not only is a kind and sympathetic manner a blessing to your patient, encouraging him giving him confidence, and helping him to summon fortitude to bear his trouble, but will be also a blessing and a vast advantage to yourself, for it will bind him to you by bonds of gratitude and affection stronger and more enduring than any amount of purely skilful treatment could call forth. You will meet with many patients who cannot appreciate the skill you may show in your treatment of their ailment, but who will repay you with warmest gratitude for sympathy with their sufferings.

\section{MEMORA NDA: \\ MEDICAL, SURGICAL, OBSTETRICAL, THERA- PEUTICAL, PATHOLOGICAL, ETc.}

HYDRORRHOA GRAVIDARUM.

Mrs. C., being nearly five months pregnant, fell down a "flight" of stairs. Severe pain came on round the waist, in the back, and down the thighs, which lasted a week, when she felt something give way, and a sudden gush of watery fluid came from the vagina. All pain then ceased. The discharge, however, continued in small amounts day and night, with the exception of intervals of twenty-four to thirty-six hours, these intermissions being invariably followed by sudden gushes. On September 17th she was confined of a healthy male child, breech presentation. The labour was rapid but otherwise natural.

The treatment has been complete rest and attention to general health, an iron tonic being given as she was anxmic. It is her second confinement, the previous one being quite natural. Arthur B. Cotteli

Surgeon-Captain Medical Staff, in charge of Staff, Female Hospital, etc., Chatham.

CASE OF POISONING BY MITSSELS.

ON the evening of September 19th, at 9 P.M., I was called to see an elderly, stoutly-built man lying on the floor of his business premises in a state of collapse, with; a very small quick pulse, and lividity of the face particularly marked about the nose. He was perfectly conscious, and there was no motor paralysis of the limbs; there was loss of speech and sight. After making several attempts at speech, I was enabled to make out that he had very acute pain at the nape of the neck, also in the epigastrium, and there was profuse diarrhoea. He said he had eaten some pears in the afternoon, but had no recollection of where he got them.

Having got him removed home and put to bed, I had mus. tard applied to the nape of the neck and epigastrium, friction to the limbs, which were cold, and the use of hot bottles. I gave him an emetic of mustard, which caused vomitin: within twenty minutes, after which he got relief, his sight and memory gradually returning.

On examining the vomited matters I found them to consist largely of mussels. With this as my only guide I instantly gave stimulants, including digitalis, together with strychnine, 10 drops of the liquor every half-hour till relieved. In four hours he was so far recovered as to state that about 6.30 P.M. on Saturday evening he had partaken freely of mussels, and about two hours afterwards he felt giddiness coming on, followed by a prickling sensation in the hands, while the throat became so dry that he "thought he was going to choke," then loss of sight quickly followed, diarrhœea being preceded by colicky pains. After this he had no recollection of anything that occurred until he found himself in bed and vomiting. I note especially that there was no smell of alcohol present, nor had he partaken of spirituous liquors.

Glasgow. Geo. Bell Todd, M.B., C.M.

\section{DOUBLE URETHRA.}

Is the interesting case of malformation reported hy Dr. Ingh Woods in the Britrsit MeDicar. Jovrnal of September 19th, pp. 614-5, and which is not altogether so uncommon as may 